\title{
Citizenship Education and Liberal Democratic Change: The Egyptian Case
}

\author{
AbdelHady M. El-Nagar (University of Manitoba) \\ Eva Krugly-Smolska (Queen’s University)
}

\begin{abstract}
This paper explores citizenship education in Egypt in the context of its current experience in liberal democratic change, especially after the amendment of Egypt's constitution, in March 2007, to include the principle of citizenship in its first article. The paper begins with exploring the meaning of citizenship, the relationship between citizenship and liberal democratic change and the emergence of citizenship education in traditional western democracies. Then it describes the Egyptian case in citizenship education with reference to its modern historical background. Finally it analyzes the effects of political, economic, and social circumstances in Egypt on citizenship education. The study shows that there is awareness of the importance of preparing good citizens for a new democratic society in Egypt; but citizenship education is still marginalized.
\end{abstract}

\begin{abstract}
Résumé
Cet article explore l'enseignement de la citoyenneté en Egypte lors du changement démocratique libéral survenu après l'amendement de la Constitution égyptienne en mars 2007 qui a inclus les principes de la citoyenneté dans son premier article. Cet article commence tout d'abord par explorer ce que citoyenneté veut dire. Il cherche ensuite à analyser la relation qui existe entre citoyenneté et changement démocratique libéral et enfin à examiner l'émergence de l'enseignement dans les démocraties occidentales traditionnelles. Il décrit par la suite le cas de l'enseignement de la citoyenneté en Egypte tout en se basant sur ses origines historiques modernes. Il analyse enfin l'influence des circonstances politiques, économiques et sociales égyptiennes sur l'éducation de la citoyenneté. Cette étude démontre l'existence d'une réelle conscience quant à l'importance de préparer de bons citoyens pour l'avenir de la nouvelle société égyptienne, bien que cette éducation soit encore très marginalisée.
\end{abstract}

\section{INTRODUCTION}

Citizenship is a deceptive word and a concept whose meaning can never be decisively fixed; it is a subject of debate and disagreement. It is a political word in the broad sense, since it is connected with questions of governance, identity, equity and justice; especially in any society, which aspires to be democratic, where citizens participate in deciding the shape of their society and govern themselves (Osborne, 2001).

The legal meaning of citizenship relates to formal membership in the nation-state, membership that carries with it a bundle of rights along with certain duties and responsibilities. The legal meaning of citizenship provides one of its dimensions; but it is a starting point for any analysis of the concept (Smith, 
1999). Based on this legal meaning, Turner (2000) states that "citizenship is an ensemble of rights and obligations that give individuals a formal legal identity, these legal rights and obligations have been put together historically as sets of social institutions such as the jury system, parliaments and welfare state” (p. 37)

According to Butenschon (2000), citizenship is "the process of gradual integration of inhabitants of the state whereby traditional and primordial authority patterns and contractual relations are replaced by legally codified universal rights and obligations" (p. 13). That is, citizenship provides the unifying force that enables people from different beliefs and backgrounds to live together cooperatively despite differing allegiances, opinions, priorities and tastes. Living together as citizens requires a framework of shared political and civic values (Halstead \& Pike, 2006).

The concept of citizenship usually raises three issues. First, is the issue of just what rights and duties attach to the status of citizen. This is a continuing point of debate, since rights and duties change with legislative process and legal interpretation, what is right or dutiful today may not be the next. Second, is the matter of just who is to possess the status quo raising questions of immigration, age and similar issues of qualification. Third, is whether rights and duties attached to the status quo are in fact enjoyed and met by all citizens, or whether some members of the community are actually 'second class citizens' deprived of access to these rights (Gilbert, 1993). And so the term citizenship is a subject of political and social debate.

In light of our study's purpose, which is to examine Egypt's case in citizenship education during its current liberal changes, Bereday's method for area studies in the field of comparative education will be used. According to this method "in area studies we speak of the descriptive phase, or geography of education, the collection of pedagogical data, and of the explanatory phase, or social analysis, the application of methods of other social sciences to interpret the pedagogical data thus assembled" (Bereday, 1964, p. 9). Consequently we will describe the Egyptian experiment in citizenship education and then, in our discussion, we will analyze and interpret this experiment in light of the different political, economic and social factors that might have affected it. However, the study starts with exploring the relationship between the idea of citizenship and liberal democratic change and the emergence of citizenship education in traditional western democracies as follows.

\section{CITIZENSHIP AND LIBERAL DEMOCRATIV CHANGE}

The word 'citizenship' was known during Greek and Roman times, but it disappeared in the medieval age until the beginning of the modern period. Its 
revival took place as a part of a transition from feudalism in Europe. The emergence and evolution of the modern concept and function of citizenship was through western traditions. It was an object of deliberation during the French revolution and coincided with the establishment of the meaning of citizenship in Britain and the United States (Eide, 2000).

The concept of Citizenship as identity was thickly interwoven with the emergence of the modern nation-state (Williams, 2003). Where everyone is equal before the law and no one is outside the law, the state commands monopolistic control over coercive means within its jurisdiction. No other authority structure in society, be it based on family, religious leadership, or tribal organization, can legitimately demand loyalty from one of its members in a way that contradicts his or her obligations toward the state (Butenschon, 2000),

The idea of citizenship was a subject of renewed interest during the debate of the Members of the European Economic Community over European citizenship. Their discussions of citizenship routinely began with T.H.Marshall's analysis which defined citizenship as a status bestowed upon those who are full members of a community. All who possess the status are equal in their rights and duties with which the status is endowed (Gilbert, 1993). T. H. Marshall in his article first published in 1950, entitled Citizenship and Social Class, divided citizenship into three parts or elements; he called these three parts, civil, political, and social. For him, the civil element is composed of the rights necessary for individual freedom and liberty of the person, like freedom of speech, thought and faith. By the political element, he means, the right to participate in the exercise of political power. By the social element, he means, the whole range of rights from a modicum of economic welfare and security to the right to share fully in the social heritage.

Marshall, for some, developed a theory for post World War II societies through an analysis of the relationships between social class, welfare and citizenship. But he was unable to incorporate ethnic and religious differences into his study of modern citizenship. His discussion is also weak in dealing with economic citizenship and the rights of women and children, and he did not analyze the impact of international contexts and globalization on citizenship (Turner, 2000).

However, more recent ideas of citizenship have built on Marshall's perspective and included new dimensions to cover post-industrial discourse on state-society relations. Scholars have introduced the concepts of cultural citizenship, global citizenship, and even ecological citizenship with reference to the current important challenges including globalization and the alleged crisis of 
the nation-state. Also there is a debate about the social rights of women, children, elderly, and even animals (Butenschon, 2000).

For Halstead and Pike (2006) there are two broad components that together make up modern citizenship. The first is a set of shared cultural, symbolic and economic practices, which draws attention to the fact that citizenship in a nation-state is inevitably tinged with the national culture, language, religion, history and tradition. The second is a set of civil, political and social rights and duties. The civil rights are balanced by the obligation to keep the law and to demonstrate a set of civil values such as honesty, tolerance, decency and self-respect. Political rights are balanced by duties like loyalty to the country, defence in time of war, and active participation in political life. Social rights are balanced by duties such as helping others through voluntary activity, community service and other forms of active citizenship.

Overall, it seems from the historical perspective that citizenship is integrally related to public authority, political processes, and moral principles that govern relationships between citizens and government. We can view such relationships in light of democratic values, which include liberty, justice, equality, and human dignity (Farquhar \& Dawson, 1979). These democratic values provide strong support for recognizing and affirming groups' identities where such groups suffer political or cultural discriminations on account of prejudice and arbitrary exclusion (Macedo, 2003). These values or principles also act as justifications for activities in public life and as guides to private behaviours. They are enduring beliefs about what is worthwhile and ideals for which people strive. There are different types of values in general; they are classified either on the basis of ideology: liberal, Marxist, Christian, Islamic, Judaist or humanist; or on the basis of different disciplines of life: political, civic, economic, cultural, moral, and scientific. Citizenship is more related to democratic and civic values (Halstead \& Pike, 2006).

\section{EMERGENCE OF CITIZENSHIP EDUCATION}

With the establishment of traditional democracies and the emergence of the citizenship idea in the West, there was a desire for the effective functioning of the democratic system, in which the individual plays an active part as voter, activist, or political party member. In order to perform these tasks, the individual must be assisted through education to know that he or she has a responsibility to be an active participant in the democratic system (Selman, 1991). Western intellectuals thought participatory democracy was the best form for citizenship education. It is connected to the real democratic exercise; democracy is learned through deliberation and participation in decision-making processes, in which 
learners act as citizens. Participatory democracy has both political and educational functions and its educational potential is likely higher than any formal or non-formal program for citizenship education (Harden, 2001).

However, there was an early awareness of education's role in preparing those citizens. In his pioneer study published in 1904, entitled The Making of Citizens: a Study in Comparative Education, Hughes had determined the purpose of this study which was to observe the result of the movement as it was taken place in the four principal countries of the world, England, France, Germany, and the United Sates. It was his aim to paint four pictures showing how these four countries endeavour to prepare their future citizens for life (Hughes, 1904, p. 3). For him "the school is a political institution maintained by the state for cultivation and propagation of national ideals. Anarchists must be born. Every school is a machine deliberately contrived for the manufacture of citizens" (Hughes, 1904, p. 4).

The writings of John Dewey, especially Democracy and Education, represented an important development in discussing the relationship between education and preparing good citizens. For him "a society which makes provision for participation in its good of all its members on equal terms and which secures flexible readjustments of its institutions through interaction of the different forms of associated life is insofar democratic. Such a society must have a type of education, which gives individuals a personal interest in social relationships and control, and the habits of mind which secure social changes without introducing disorder" (Dewey, 1961, p. 99).

Merriam (1966), in his important work entitled The Making of Citizens discusses many mechanisms for making citizens. He also believes "the school system is the basic factor in the development of civic interest and loyalty, and the chief instrument for that purpose...in the scheme of civic education it looms largest in the series of techniques employed to develop civic feeling and allegiance"(p. 134). The key question was: In what way does the school have an effect on citizenship development? Farquhar and Dawson (1979) provided answers as follows:

- The school has its greatest impact through the transmission of political information; its importance increases from elementary to high school.

- The school's impact is greatest for low social status and minority populations.

- $\quad$ The teacher has some modest impact on student attitudes. Through his or her influence on classroom climate the impact can be highly influential.

- $\quad$ Systematically designed treatments can result in considerable transmission of and increase in political information at all age levels. 
- Participation in school governance and extra-curricular activities relates positively to political attitudes.

In the last two decades, the state of public morality and the prospects for civic culture emerged as central themes for liberal thinkers; emphasis has been given to the state as educator of the next generation of citizens. Attention has, in particular, been paid to the schoolroom. There is an assumption that the school represents a unique opportunity to inculcate appropriate dispositions in the populace at large. Educationists maintain that social responsibility and civic awareness are easier to cultivate earlier in life (Kenny, 2004).

For Selman (1991), education in relation to citizenship falls into three main areas: First, it is about the intellectual powers of individuals and how to take part in the political process. This area has traditionally been the focus of 'liberal education' that equips the individual with powers of analysis and expression, which enable him or her to be a citizen. Second, it is about how the political system works and how it can be influenced. This is often known as 'civics education' and particular emphasis is on the young and recent immigrants. Third, it is about particular issues, this is the focus of what is termed 'education about public affairs'.

\section{GOALS OF CITIZENSHIP EDUCATION}

The term of "citizenship education" is more comprehensive. It refers to institutionalized forms of political knowledge, values, and attitudes that take place within formal and informal educational frameworks. The content of citizenship education is complex and multidimensional in nature and it varies in time and space depending on the nature of the political system. It is often used in different forms including political education, moral education, civics, political literacy, and nationalistic education (Choi, 2000).

This complexity in citizenship education's nature and content resulted in a debate over its goals. Citizenship education may be narrowly or broadly conceived. In the narrow sense it aims to produce citizens capable of addressing political arguments posed by democratic debate. In the broader sense its aim is to create citizens who share in a common social endeavour (Halstead \& Pike, 2006). Since citizenship education is a vast field of education that includes a wide range of philosophical, ideological perspectives, educational approaches, and consequently goals and practices, so there is a general consensus that the main purpose of citizenship education is the development of good democratic citizens. In terms of implications, which include educational policies, curriculum development, and pedagogical strategies (Schugurensky \& Myers, 2003), it aims specifically at providing learning opportunities for gaining the knowledge, skills, 
attitudes, and experiences requisite to effective, responsible citizenship. Such opportunities vary according to the needs and experiences of learners. They should respond to the key issues of citizenship in a changing world, and to the characteristics of diverse learners, who include adult citizens, resident aliens, as well as children of all ages who are in the process of becoming citizens (Farquhar \& Dawson, 1979).

\section{TEACHING CITIZENSHIP}

Achieving these aims, consequently, requires more than just the betterment of courses of study or school-based programs, because of its contested meaning and education for democratic citizenship is neither age nor institution bound. It is an endeavour that is of concern to every one in a democratic society (Branson, 2002). There are different approaches to teaching, as sometimes its instruction subordinates other subjects in the curriculum, particularly social studies, where it may appear under the heading of democratic understanding and civic values or as a freestanding unit. In other cases it appears as the outcome of another subject, or it may be presented as a series of imperatives permeating the whole curriculum and each individual subject. Sometimes it is defined in the literature as a crosscurricular theme and not as a separate and distinguishable domain of the curriculum (Lynch, 1992).

Whatever the disagreement over the nature of citizenship education, it consists of key elements whose identified aspects were summarized above. These elements which comprise the different programs of citizenship education including; a sense of identity, an awareness of one's rights and respect for the rights of others, the fulfilment of duties, a critical acceptance of social values, political literacy, a broad general knowledge and command of basic academic skills, and the capacity to reflect on the implications of all these components and to act appropriately (Osborne, 2001).

\section{CITIZENSHIP EDUCATION IN EGYPT}

Throughout the previous outline it seems that there is a relationship between liberal democratic change in traditional western democracies and the emergence of the concepts of citizenship and citizenship education. A report for UNESCO states that "education for citizenship, as it is sometimes known, has acquired particular significance in countries that have recently adopted democratic political systems, but it has also drawn concern in countries where such systems have long been established" (UNESCO, 2000, p. 80). In light of that discussion we explore citizenship education in Egypt, in the context of its current liberal change experiment, starting with the modern historical background. 


\section{HISTORICAL BACKGROUND}

The modern history of Egypt usually starts with the reign of Mohamed Ali (1805-1848) the founder of modern Egypt. He not only built a national Army, but also constructed an impressive educational system. Under M. Ali, a daring attempt to build up state capitalism was launched, and the early inklings of a concept of citizenship, or nationality, emerged (Ayubi, 1991). With the beginning of the nineteenth century, the national spirit of Egypt revived as a result of European influence. Mohammad Ali wished to build up a modern state with strong armed forces. A school system was created to provide the required manpower for the army and civil bureaucracy. In 1837 he founded the central Ministry of Education, which controlled the majority of the educational institutions in Egypt (Moehlman, 1968).

Khedive (Ruler) Ismail (1863-1879) helped to create Egyptian nationalism by financing the earliest daily newspaper, setting up government schools, convoking the first representative assembly in 1866, and establishing the mixed courts in 1876. That nurtured a new class of educated Egyptians who called for an articulate response to what was happening in their country. Some of them joined the army officers to form Egypt's first nationalist movement (Goldshmidt, 2004).

The concept of Egyptian citizenship received its main boost on the occasion of the 1919 nationalist revolution against the British occupation of Egypt. As a corollary to the revolution, another attempt to build up the economic upon the national bases was launched by the Banque Misr group in the 1920s. But this was eventually taken over by foreign business interests (Ayubi, 1991). The revolution of 1919 was an Egyptian national movement, which sought full independence for Egypt. This was the motive dominating Egyptian politics from that time until the British withdrawal in 1954. This type of nationalism was a potent force but it was not a coherent system of ideas for a political programme (Hopwood, 1982).

In 1922 Egypt declared independence, which was hedged by a number of restrictions. However, a constitutional council was given the task of preparing a constitution; a liberal experiment was about to be tried in Egypt. That experiment was supposedly to grant Egypt a constitutional form of government, freedom of speech, the right to opposition, and democratic, representative government (Marsot, 2007). After independence, the parliamentary elections, political parties like the Wafd and the Liberal Constitutional Party, and a new vision of an independent liberal democratic society emerged. The leaders of these parties saw 
themselves as responsible for spreading the theory of liberal democracy among their people (Mayer, 1988).

Egyptian intellectuals supported liberalism, embraced nationhood and citizenship as the valid identity. It was necessary to rewrite Egypt's history, culture and literature (Maghraoui, 2006). The state-controlled educational system worked to provide an alternative Egypt-centred national identity. Courses in civics education and civic syllabuses were drafted; their purpose was to promote a sense of nationalism through the understanding that in spite of the successive invasions and foreign domination, which plagued Egypt throughout its history, Egypt remained an independent entity (Gershoni \& Jankowski, 1995).

The 1923 Constitution defined the relationships of power and established a masculine character of the nation by only recognizing adult male citizens as members. It gave only them the right to vote in general elections and participate in the national government (Hatem, 2000). With the absence of clear and coherent concepts of public authority, rights and duties in liberal writings, the Egyptian liberals held that in a culturally backward society the masses do not have the capacity to make meaningful choices (Maghraoui, 2006).

The Free Officers group's revolution in 1952 represented, especially under Nasser's leadership, another attempt at building both the institutional and the economic foundations of the modern state. The banners of this time were more socialist and the concept of social justice was more pronounced (Ayubi, 1991). The concept of citizenship was slow to spread until the 1952 revolution; it devolved in both intensity and extent in Egypt and the Middle East especially under Nasser (1954-1970) (Goldschmidt, 2004).

During this time the concept of Arab Nationalism emerged. Arab nationalism has been a key feature of Egyptian citizenship. It is a concept that represents a developing phase in the growth of the citizenship concept in Egypt and the Arab world. It was a "belief that all those who are Arab by language, history, and culture form a natural unity and that political unity in the face of the rest of the world is a necessity. All Arab leaders paid homage to this feeling but in practical terms little was achieved. The unity of language, religion of the majority, and cultural heritage has given to most Arabs a feeling of brotherhood, but political or economic union has not been achieved” (Hopwood, 1982). The idea of uniting all Arab countries appealed to many citizens, and it did not exclude Arabic-speaking Christians. It would combine all Arab countries together after their independence from the foreign powers (Goldschmidt, 2004).

The Free Officers turned their attention towards educational reform and gradually attempted to bring education within an overall plan for the country's development. With the introduction of ideological programmes, more attention 
was paid to politicising education and to relating it to planned changes in society in general (Hopwood, 1982). The 1956 constitution emphasised Arabness as a key feature for the Egyptian people, as a part of the Arab nation. This gave them a clear ethnic and linguistic identity (Hatem, 2000). Following the 1958 union with Syria, new courses on 'Arab society' entered the curriculum and a new series of history textbooks was published. It aimed at covering the modern and contemporary history of the Arabs including Egypt. The authors of these books paid increasingly more attention to Egypt's historical ties with and role in the Arab region (Mayer, 1988).

The idea of Arab nationalism was shared by thousands of students, military officers, and intellectuals throughout the Arab world. It rapidly became the dominant political ideology of the region; its message was both simple and powerful. However this movement had historically lacked a dominant leader capable of marshalling its diverse and conflicting factions (Palmer, 1997).

\section{THE CURRENT LIBERAL CHANGE EXPERIMENT}

After the war of October 6th 1973, during Sadat's Rule (1970-1981), Egypt changed its direction towards political, economic and social liberalism. Politically, it moved from one party defined as the political organization; it shifted to several platforms within the party and then to a small number of parties. From a very tightly controlled press, Egypt moved toward greater freedom in the press. From nomination of candidates for political office by the Arab socialist union, it moved to an almost complete freedom of candidacy. Also Egypt moved from rigidly controlled elections to more free and competitive elections (Cooper, 1982). The aim of political liberalization was to encourage foreign capital investment in Egypt. Sadat's motives for liberalizing the political system were influenced by economic priorities rather than a desire for genuine democratization. This assumption is supported by the nature of the law No. 40, issued in 1977, which was issued to constrain the establishment and activities of political parties in Egypt (Kassem, 2004).

Economically, during the last two decades, the adoption of market economy approaches had required the modernization of processes and systems that help in addressing the citizen's need through relevant legal frameworks and institutional development. To achieve this goal, the government of Egypt has acknowledged the necessity of opening wider prospects for freedom of opinion and expression and by progressing gradually toward a well-established democracy. As a consequence the government has set objectives that include, improving the capacity and efficiency of the public administration system, civil 
service reform, and the reinforcement of the country's legal framework (United Nations, 2001).

Socially, Egypt's permanent constitution of 1971 stipulated in its eighth Article that "The state guarantees equality of opportunity to all citizens". And in the fortieth Article the constitution stipulates "All citizens are equal before the law, they have equal public rights and duties without discrimination on the base of race, ethnic, origin, language and religion or creed” (A.R.E., 2007). Recently, in March 2007, Egypt conducted an important amendment in the constitution to stipulate in its first Article "The Arab republic of Egypt is a democratic state based on citizenship...” Thus, the constitution emphasises citizenship as a main principle that governs the relationship between the state and all people on the basis of equality of opportunity regardless their religion, race, sex, and so on. It represents an important social evolution in Egypt.

\section{CITIZENSHIP EDUCATION}

In context of the current liberal change experiment, which started during the mid of 1970s, Egypt tried to bring to education a more open approach, not rigidly based on a socialist ideology. The search was being made for a uniquely Egyptian solution rather than a ready-made educational pattern to be implemented. Sadat believed that the preservation of Egyptian national characteristics through education is as important as innovation. It was yet another aspect of his idea of continuity with change. From a liberal outlook there was a search for an appropriate development for the educational system (Hopwood, 1982).

In our exploration for citizenship education in Egypt we start with education law No. 139. It was issued in 1981 and amended many times to regulate pre-university education in Egypt. The law states in its sixteenth article that "the purpose of basic education is developing the students' abilities and readiness, and providing them with the necessary and sufficient values, knowledge, and scientific, vocational skills that are suitable for different local environments. Also enabling the pupil who completes basic education to pursue education in a higher stage or to face life after intensive vocational training, this is to prepare the individual to be a productive citizen in their environment and community". Thus the law emphasises the importance of appropriate preparation of the pupil as a productive citizen.

There are also many official documents that clarify Egypt's awareness of citizenship education and preparing students for a democratic life. A recent policy document from the Ministry of Education (2000) states that "The potential dominance of technology over culture and civilization will necessitate strenuous 
efforts to deepen the values of loyalty and belonging among Egyptian citizens, to affirm Egyptian identity and reinforce all which pertains to our civilization and cultural heritage; thus, we can not discard ethical values such as appreciation of beauty, happiness, peace and stability originating from family life or noble human values such as friendship, respect for others" (Ministry of Education, 2000, p. 114). Within that context a number of national conferences were held to study the various stages and types of education. Specifically they have focused on supporting national unity, development of Egyptian identity throughout the educational process, strengthening students' sense of belonging, and integrating democratic values (Ministry of Education, 2003).

Extra curricular activities have also become a complementary part of the comprehensive education reform strategy, which aims at creating good citizens. There are important achievements regarding that including activating students' unions. The main goal is supporting the principle of democracy in the minds of the students through the different experiences and the belief in national unity between Muslims and Christians as a strategy for social peace (Ministry of Education, 2000).

Although this theoretical awareness of the importance of preparing good citizens appropriately for a rising democratic society in Egypt, we do not find an existing program, with specific goals for teaching citizenship in the public schools. Consequently the education system in Egypt is still far from the genuine principles of citizenship education, especially in the field of promoting democratic values in the educational process and enabling students to participate in the decision-making process through educational activities (Mougheeth, 2002). There are also some problems that challenge citizenship education in Egypt, and basically include the following:

\section{Curriculum}

Educational institutions in Egypt do not yet include the culture of civic society through the curricula. On the contrary, they are still traditional institutions based on traditional curricula that do not prepare suitable citizens for social participation (Abdelhamid, 2002). A prime example of this is the environmental curriculum. In spite of efforts to make the environment an integral part of the school curriculum, it failed to provide students with basic environmental information. Hence it did not help students to develop positive attitudes towards the environment and its problems. This was attributed to shortcomings in the curriculum itself in addition to the teachers' failure to address environmental issues or to fulfil the goals of environmental education. Research shows that 
teachers did not get any in-service training with the new curriculum; in addition, teacher handbooks were not available for teachers (UNESCO, 1999).

\section{Teachers}

Many studies emphasized that the prevalent problem among teachers is still the lack of skills of human and social relations and of participation that can enable pupils to make decisions, choose among alternatives and acquire the skills of social behaviour (Abdelhamid, 2002). An international project started in 1999 had, as its aim to provide teachers with the necessary communication skills and training to disseminate democratic values among their pupils. Topics in the program included basic aspects such as the use of participatory and creative learning processes and the role of the teacher in a democratic classroom. The project was popularly received; however, the governmental response illustrated less interest in such an initiative (Kassem, 2004). Studies recommended that to achieve the intended learning impact, all teachers in Egypt have to be fully familiar with the new teaching and learning materials, the new pedagogical approaches, new educational technology, and they have to be capable of effectively using them in the classroom. Obtaining this type of teacher can be made through a rolling review of the entire system of teacher training (UNESCO, 1996).

\section{Educational Administration}

Egypt has a well-developed, central administration structure to provide educational services and supervision in a large educational system. The structure essentially has three levels, the central level in Cairo with the Minister and the Ministry of Education, education offices in each of the twenty-seven governorates or provinces, and education offices in the districts of each governorate. The local schools within each district have a director and a deputy and each school must have a parent-teacher council that participates in school management and decision-making (UNESCO, 2003). The education system at all levels is highly centralized, with fragmented units and departments within the central ministry duplicating and sometimes undermining each other's work. Overstaffing of administrators has resulted in the loss of efficiency, innovation and effectiveness at the school level (United Nations, 2001).

Discipline, obedience, oppression, and commitment are the principal aspects of the educational system, which begin with the decision makers at the top level and extend to pupils in the classrooms. School directors follow instructions and teachers concern themselves with inspections and textbooks leaving the pupils to follow the books and their instructions. These circumstances 
resulted in the dominance of paper work in the state educational system because its priority lies in following instructions. As a consequence, the concept of citizenship education disappears from the Egyptian educational system (Mougheeth, 2002).

\section{DISCUSSION}

The question that arises here is why this weakness or marginalization of citizenship education in Egypt? There is still a gap between the discussed meaning of citizenship education in traditional western democracies and the Egyptian case. Our study tries to interpret this weakness in light of the political, economic, and social factors as follows.

\section{Political Factors}

Egypt during the time of Sadat changed its political ideology from socialism and one political organization to liberalism and a multi-party system. The Egyptian constitution states in its fifth article "the political system of the Arab Republic of Egypt is a multiparty system within the framework of the basic elements and principles of the Egyptian society as stipulated in the constitution. Political parties are regulated by law...." It is seen that concrete progress has been made toward democracy during the last few years. It seems from the elections of the People's Assembly members, the electorate has meaningful choice among candidates and there are also a number of vocal political parties. While progress has been made, much remains to be done (Palmer, 1997).

The concept of competition in the democratic system requires free multiparty elections based on universal franchise, free speech, and conduct according to formal rules that adjust the electoral process, and do not advantage one contestant over another. Egypt has had multi-party elections for parliament since 1976, but neither they nor local councils' elections meet these criteria (Elghonemy, 2003).

The shortcoming in the Egyptian liberalization can be attributed to three factors. First is the distribution of power between institutions. Second are the class interests, which are very sharply formulated. This made it difficult to moderate political conflict that could be contained within the political institutions. Third, it is clear that the individuals involved in the political process lacked the skills and the clear political concept of liberalization necessary to execute the change successfully; they mismanaged the process (Cooper, 1982).

That political climate influenced the educational institutions, which are still enclosed and do not work for either spreading civic society's culture or preparing the pupils to engage in the political reality and the issues around them. 
Moreover they do not provide the pupils with the skills of interactivity, participation, problem solving and awareness of their surroundings or to accept others' opinion and the legitimacy of differences (Abdelhamid, 2002).

\section{Economic Factors}

Sadat inaugurated Egypt's first step in its march along the path of market economy by presenting October's paper in 1974. 'El-Inftah' or Egypt's economic opening to the west was the cornerstone of that shift in policy. This opening explicitly focused on promoting development and solving Egypt's economic problems by encouraging the acquisition of finance and technology from outside. It presented a new vision of the balance between the private and public sectors (Gomaa, 1996).

The economic open-door policy has proceeded along two complementary courses. The first focused on activating the role of the private sector in the development process through specific steps including attracting Arab and foreign investments, opening up importation avenues to private capital, and signing an agreement with the International Monetary Fund and World Bank in 1991 on an economic reform program. The second was public-sector development, which ranged from separating administration from ownership to granting more freedom of action to public companies (Mossad, 1996).

In spite of the liberal shift in these economic policies, the Egyptian constitution still states in its article 23 that the "national economy is organized in accordance with a comprehensive development plan, which ensures increase of national income.” Thus, the Egyptian economy is still planned according to the constitution. The El-Inftah policy was an initiative to revive the Egyptian economy by lifting Nasser's socialism. Thus Egypt possesses a mixed economy, not a liberal one, in which private-sector firms were free to compete with the public-sector firms (Palmer, 1997)

Studies indicate that the inadequate legal framework of the Egyptian economy does not provide mandatory provisions that force or encourage the government to implement the privatization program or speed up its process (Mohieldin \& Nasr, 1996). The legal reform, undertaken in the institutional framework of economic activities, is necessary but not sufficient for a speedy development and for realizing the current perception of partnership between government and the private sector (El-ghonemy, 2003). The economic policies, which are still far from economic liberalism "have created new cultural patterns and encouraged uncivil attitudes and behaviour regarding the law including disrespect, evasion, or out-right violation. They have moreover contributed to citizens' lack of trust in public institutions and officials, disincentives to work, 
nonachievement, disinterest in the public good and cynicism” (Harik, 1997, p. 193).

\section{Social Factors}

The economic policies resulted in social problems including widened class differences. Many citizenship rights have been frozen, such as the one promising equality of opportunity. For example, the state's withdrawal from the provision of social services made equality of opportunity subject to the whims of the market (Hatem, 2000).

In the social context also, the family still is the core social institution in the Arab region in general. Almost all of the Arab countries, including Egypt, define the family as the basic unit of society in their constitutions (Joseph, 2000). Consequently, loyalty to the family, in many cases, is stronger. There had existed an ingrained instinct that the family's most intimate ties had to be preserved (McDermott, 1988). For instance the preferred pattern of marriage among people is marriage between paternal parallel cousins and relatives (Joseph, 2000).

These facts in Egyptian social life created a sense of victimization and contributed to the generation of devious public conduct. They engendered a culture in which disrespect for the law became a general rule, in effect undermining civic norms. Most disturbing is the feeling by more of the citizens that evading or violating the law is a legitimate act and an unquestionable personal right to be claimed. Public policy that was perceived to be unfair generated antilegal attitudes and corrupt behaviour (Harik, 1997).

Thus it seems obvious that political, economic and social factors have affected citizenship education negatively and do not offer a suitable opportunity for teaching citizenship in Egypt.

\section{CONCLUSIONS}

This study asserts that participatory democracy is the best form for citizenship education. It is connected to the real exercise of democracy. Participatory democracy has both political and educational functions and its educational potential is likely higher than any formal or nonformal program for citizenship education.

From a historical point of view, the Egyptian meaning of citizenship received its main boost from the 1919 nationalist revolution against British dominance over Egypt. Another attempt to build up the economic bases of the nation-state was in the 1920s. The concept of citizenship was slow to appear and spread in Egypt, until the 1952 revolution. It devolved in both intensity and extent in Egypt 
and the Middle East especially under Nasser 1954-1970. In this time the concept of Arab nationalism emerged. Arab nationalism represents a developing phase in the growth of the citizenship concept in Egypt.

In the context of Egypt's change towards economic and political liberalism, there was awareness of the importance of preparing good citizens for a democratic society in Egypt. Many official documents clarify the Egyptian interest in that respect. But the public education system in Egypt is suffering from many problems that prohibit its march towards reform and development. Education is still far from the genuine principles of civic education. These problems basically include curriculum, teachers' preparation and educational administration.

Unlike the traditional democracies in the west, the political, economic and social factors do not offer a suitable opportunity for teaching citizenship in Egypt. There is still a gap between the meaning of citizenship education in the traditional liberal democracies and the political, economic and social reality in Egypt.

In light of the previous, the study recommends that it is important for Egypt to establish a suitable and appropriate approach for citizenship education. The Constitution's amendment gives us a good starting point to amend education law No. 139/1981 and educational policies towards more attention to educating citizens for the desired democratic society. Studying the experiences of other democratic societies in this respect is also recommended. 


\section{References}

Abdelhamid, E. (2002). Curriculum and developing civic education culture. In K. Mougheeth \& M. Darwish (Eds.), Civic education in Arab world. Amman: Arab civic Education Network. pp. 58-69.

Arab Republic of Egypt, (2007). The permanent constitution of 1971 . Available at: http://www.sis.gov.eg/En/Politics/Constitution/Text/htm.

Arab Republic of Egypt. (2000). The Law of education No.139/1981. Cairo: Al-Ameriah Press.

Ayubi, N. (1991). The State and public politics in Egypt since Sadat. U.K.: Ithaca Press.

Bereday, G. (1964). Comparative method in education. New York: Holt, Reinhart and Winston, Inc.

Branson, M. (2002). Civic education: An international perspective. In K. Mougheeth \& M. Darwish (Eds.), Civic Education in Arab world. Amman: Arab Civic Education Network. pp. 18-29.

Butenschon, N. (2000). State, power and citizenship in The Middle East: A theoretical introduction. In N. Butenschon et al (Eds.), Citizenship and the state in the Middle East. USA: Syracuse University Press. pp. 3-27.

Choi, T. (2000). Civic education in transition: The case of Hong Kong. Canadian and International Education, 29(1), 1-14.

Cooper, M. (1982). The Transformation of Egypt. London: Croom Helm.

Dewey, J. (1961). Democracy and education. New York: The Macmillan Company.

Eide, A. (2000). Citizenship and international human rights Law. In N. Butenschon et al (Eds.), Citizenship and the state in the Middle East. USA: Syracuse University Press. pp. 88-122.

El-Ghonemy, M. (2003). Egypt in the twenty first-century: Challenges for development. London: Routledge.

Farquhar, E., \& Dawson, K. (1979). Citizen education today: Developing civic competencies. USA: US Office of Education.

Gershoni, I., \& Jankowski, J. (1995). Redefining the Egyptian nation 1930-1945. London: Cambridge University Press.

Gilbert, R. (1993). Education for active citizenship and the Problem of Identity. In K. Kennedy and Others (Eds.), Citizenship Education for a New Age. Australia: University of Southern Queens land. pp. 87100.

Goldschmidt, A. (2004). Modern Egypt. USA: Westview Press.

Gomaa, S. (1996). The civil society debate over privatization in Egypt: Conflicting interpretation and goals. In W. Badran \& A. Wahby (Eds.), Privatization in Egypt: The debate in the people's assembly. Cairo: Centre for Political Research and Studies, Cairo University. pp. 149-178.

Halstead, M,. \& Pike M. (2006). Citizenship and moral education: Values in action. London: Routledg.

Harden, A. (2001). Education, globalization and citizenship: Toward an additional component of citizenship based on economic globalization. Unpublished M. Ed. Dissertation, Faculty of Education, Queen’s University.

Harik, I. (1997). Economic policy reform in Egypt. USA: University Press of Florida.

Hatem, M. (2000). The pitfalls of the nationalistic discourses on Citizenship in Egypt. In S. Joseph (Ed.), Gender and citizenship in the Middle East. USA: Syracuse University Press. pp. 33-57.

Hopwood, D. (1982). Egypt: politics and society 1945- 1981. UK: George Allen \& Unwin Publishers.

Hughes, R.E. (1904). The making of citizens: A study in comparative education. London: The Walter Schott Publishing.

Joseph, S. (2000). Gendering Citizenship in the Middle East. In S. Joseph (Ed.), Gender and citizenship in the Middle East. USA: Syracuse University Press. pp. 3-30.

Kassem, M. (2004). Egyptian politics: The dynamics of authoritarian rule. UK: Lynne Rienner Publisher.

Kenny, M. (2004). The politics of identity: liberal political theory and the dilemmas of differences. UK: Polity Press.

Lynch, J. (1992). Education for citizenship in a multicultural society. New York: Cassell.

Macedo, S. (2003). Liberalism and group identities. In K. McDonough \& W. Feinberg, (Eds.), Education and Citizenship in liberal-democratic Societies. UK: Oxford University Press. pp. 414- 436.

Maghraoui, A.M. (2006). Liberalism without democracy: Nationhood and citizenship in Egypt, 1922-1936. London: Duke University Press.

Marshall, T.H. (1950). Citizenship and social class. Cambridge: the University Press.

Marshall, T., \& Bottomore, T. (1992). Citizenship and social class. London: Pluto Press.

Marsot, A.L. (2007). A History of Egypt. UK: Cambridge University Press. 
Mayer, T. (1988). The Changing past: Egyptian historiography of the Urabi revolt 1882-1983. USA: University of Florida Press.

McDermott, A. (1988). Egypt from Nasser to Mubarak: A flawed revolution. London: Croom Helm.

Merriam, C.E. (1966). The making of citizens. USA: Colombia University Press.

Ministry of Education. (2000). Mubarak and education: Towards Excellence for all. Cairo: Book Sector.

Ministry of Education. (2003). Education achievement in Egypt. Cairo: Book Sector.

Moehlman, A. (1968). Comparative education systems. New York: The Centre for Applied Research in Education.

Mohieldin, M., \& Nasr, S. (1996). On privatization in Egypt: With reference to the experience of the Czech Republic and Mexico. In W. Badran \& A. Wahby (Eds.), Privatization in Egypt: The debate in the people's assembly. Cairo: Centre for Political Research and Studies, Cairo University. pp. 19-71.

Mossaad, N. (1996). The process of privatization in the Egyptian party discourse. In W. Badran \& A. Wahby (Eds.), Privatization in Egypt: The debate in the people's assembly. Cairo: Centre for Political Research and Studies, Cairo University. pp. 73-147.

Mougheeth, K. (2002). Civic education in Egypt. In K. Mougheeth \& M. Darwish (Eds.), Civic education in Arab world. Amman: Arab Civic Education Network. pp. 104-112.

Osborne, K. (2001). Public schooling and citizenship education in Canada. In R. Bruno \& N. Aponiuk (Eds.), Educating citizens for a pluralistic society. Alberta: Canadian Ethnic Studies Journal, University of Calgary. pp. 11-48.

Palmer, M. (1997). Comparative politics: Political economy, political culture, and political interdependence. USA: FE Peacock Publishers, Inc.

Schugurensky, D., \& Myers, J. (2003). Citizenship education: Theory, research and practice. Encounters on Education. 4, 1-10.

Selman. G. (1991). Citizenship and the adult education in Canada. Vancouver: The Centre for Continuing Education, University of British Columbia.

Smith, L. (1999). Is citizenship a gendered concept? In A. Cairns and others (Eds.), Citizenship diversity \& pluralism. Canada: McGill-Queen's University Press. pp. 137-162.

Turner, B. (2000). Islam, civil society, and citizenship: Reflections on the sociology of citizenship and Islamic studies. In N. Butenschon et al (Eds.), Citizenship and the state in the Middle East. USA: Syracuse University Press. pp. 28-48.

UNESCO. (1996). Review and assessment of reform of basic Education in Egypt. Cairo: UNESCO office.

UNESCO. (1999). Environmental education in Egypt. Cairo: UNESCO office.

UNESCO. (2000). The right to education: Towards education for all throughout life. Paris: UNESCO.

UNESCO. (2003). Educational reform in Egypt 1996-2003. Cairo: UNESCO office.

United Nations. (2001). Egypt, common country assessment. Cairo: United Nations Office.

Williams, M. (2003). Citizenship as identity: Citizenship as a shared fate, foundations of multicultural education. In K. McDonough \& W. Feinberg (Eds.). Education and citizenship in liberal-democratic societies. UK: Oxford University Press. pp. 208-247.

\footnotetext{
AbdelHady M. El-Nagar is an Affiliate Researcher in the Department of Educational Administration, Foundations and Psychology of the Faculty of Education at the University of Manitoba and can be reached at dr_elnagar@yahoo.ca
}

Eva Krugly-Smolska is an Associate Professor in the Faculty of Education at Queen's University and can be reached at kruglye@queensu.ca. 